Article

\title{
Analysis and Design of Customer Satisfaction Systems Against the Technicians from the Repair Service of Photocopy Machine At PT Copindo Renanta Using the SAW Method
}

Thessa Seftiani Dewi ${ }^{1}$, Dram Renaldi, M.Kom ${ }^{2}$,

${ }^{1,2}$ Buddhi Dharma University, Information System, Banten, Indonesia

\begin{tabular}{l}
\hline SUBMISSION TRACK \\
\hline Received 20 June 2019; \\
Revised 20 July 2019; \\
Accepted 10 September 2019; \\
Available online 20 September 2019 \\
KEY WORD \\
\hline
\end{tabular}

Customer, Repair Services Order, Performance Assessment, Technician, SAW.

\section{CORRESPONDENCE}

E-mail:

thessaseftiani@gmail.com

dram.renaldi@ubd.ac.id

\begin{abstract}
A B S T R A C T
For companies that work in the services sector, service quality is something very important to establish long-term relationships with its customers. At this time, PT Copindo Renanta evaluates the performance of technicians by provide a service satisfaction forms that made from a paper for the customer against the technician performance that can be manipulated by the technician so that the company cannot assess customer satisfaction with the true service of the technicians. The making of customer satisfaction system against the technicians from the repair service of photocopy machine at PT Copindo Renanta using the SAW method can provide an accurate and trusted results of technician performance calculations from photocopier repair services because calculations are carried out using the SAW method based on several values from the criteria by the customer filled. The system also supports a process of the order a copy machines repair services for customers who want to repair their machines (only need an internet connection and web browser to access and use anywhere and anytime needed, no need to wait for working hours), and support companies to make a technician performance assessment report till a repair photocopy machines transactions report.
\end{abstract}

\section{INTRODUCTION}

PT Copindo Renanta is a company that work in the sector of fotocopy machines repair services in Tangerang city. At this time, PT Copindo Renanta still do an assessment against technician by manual that PT Copindo Renanta still uses paper media for service satisfaction forms provided by technicians to be filled by customers after the machine has been repaired. The completed service satisfaction form will later become the material for PT Copindo Renanta's technician service improvement to support the better performance of the technicians. But in over time, the assessment of technicians using the customer satisfaction forms has not gone as expected by the company. The technician manipulates the assessment by fill the form by themselves become a thing that are less of concern so that the company cannot assess customer 
satisfaction with the true service of the technicians.

Customer satisfaction system for photocopier repair service technicians is certainly awaited thing for the company and customers, because with this system the performance appraisal of technicians can be more accurate and more trusted with customers filling their own satisfaction agains the technicians who come to repair their copy machines so PT Copindo Renanta is easier to find service improvement materials for the technicians because it can calculate the ranking of the best technicians using the SAW method, good technicians service will be able to continue to be maintained and technicians service that are not good enough will be pay attention even more where the shortcomings of the technicians to be given more learning / training. This system can also support transaction orders for photocopier repair services for customers because they can access and use wherever and whenever needed, no need to wait working hours, also provides convenience for the company in making reports, complete with the calculation of the best technician rankings using the method SAW on the report on the performance evaluation of a photocopier repair service technician..

\section{METHOD}

\section{The definition of System Analysis}

The system is a collection of interrelated elements and is responsible for processing input (input) so as to produce output (output) [2].

The understanding of the system as follows [3]:

a. A group of elements that are interconnected and form a unity.

b. A group of components working together towards a common goal by receiving input and producing output in a regular transformation process.

c. An assembly of methods, procedures, or techniques that are united by regulated interaction to form an organizational unity. d. A set of people, machines, and methods that are organized and needed to complete a certain set of functions.

Systems analysis is a set of procedures for creating new information system specifications or modified information systems [1].

Following are the steps in system analysis :

a. Study and document the existing system.

b. Complete analysis documentation. System analysis documentation includes: observations and interviews, summaries of questionnaire results, flowcharts, DFD, organizational structure.

c. Designing new system alternatives.

d. Choose the best system alternative. After deciding to choose the best alternative system, then the next decision is needed about the resources that will be used in the implementation of the system, including computer software and hardware.

It can be concluded that system analysis is a procedure used to make specifications in making modifications or making new systems.

\section{WWW (World Wide Web)}

The WEB" / "W3" is a system on the internet that has the facility of searching and providing fast information using hypertext technology [4].

WWW (World Wide Web) or website is a facility on the internet that displays information in the form of text, images and sound in a very interactive multimedia [4].

So that the website is a facility on the internet that can search and provide information quickly and interactively.

\section{The definition of Decision Support System} Decision Support System is, "A computerbased system that helps in the decision making process, to support solutions to management problems that are not structured [5].

Benefits of SPK Decision Support System:

a. SPK broadens the ability of decision makers to process information data for their users. 
b. DSS helps decision makers to solve problems, especially various problems that are very complex and unstructured.

c. SPK can produce solutions more quickly and results can be reliable.

d. Although an SPK may not be able to solve the problems faced by decision makers, but it can be a stimulant for decision makers in understanding the problem, because it is able to present various alternative solutions.

So it can be understood that SPK is a computer-based system that has many benefits in supporting and helping provide solutions to the decision making process for unstructured problems.

\section{Simple Additive Weighting (SAW)}

SAW method, the rating or value of each attribute must have passed the previous normalization process. Normalization of the decision metric $(\mathrm{X})$ to a scale which can later be compared to all existing alternative values [6].

The formula for carrying out this normalization process is as follows:

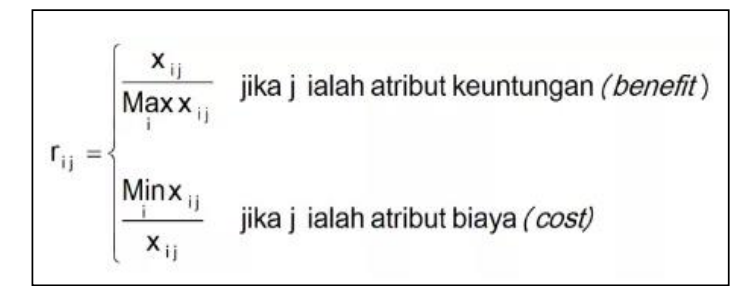

Figure 1: The Formula of SAW Methods

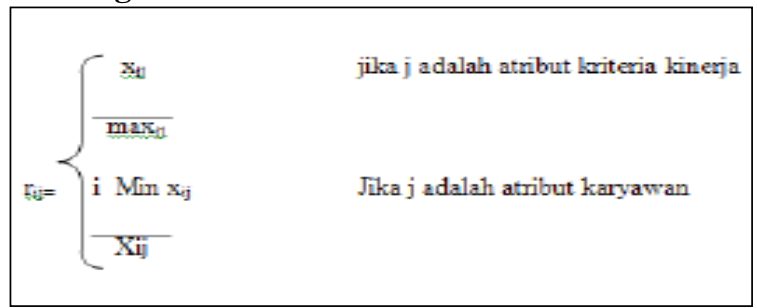

Figure 2: Explanation of the Simple Additive Weighting Method Formula

The preference value for each alternative (Vi) is calculated as follows:

$$
\begin{aligned}
& V_{1}=\sum_{j=1}^{n} w_{1} r_{1 j} \\
& \text { Keterangan : } \\
& V i=\text { rangking untuk setiap alternatif } \\
& \text { wj = nilai bobot dari setiap kriteria } \\
& \text { rij = nilai rating kinerja ternormalisasi }
\end{aligned}
$$

Figure 3: Rumus Metode Simple Additive

$$
\text { Weighting }
$$

\section{Steps for using the SAW method:}

1) Determine the criteria that will be used as a reference in making decisions, namely $\mathrm{Ci}$.

2) Determine the suitability rating of each alternative on each criterion.

3) Make a decision matrix based on criteria (Ci), then normalize the matrix based on an equation that is adjusted to the type of attribute (profit attribute or cost attribute) in order to obtain the normalized matrix R.

4) The final result is obtained from the ranking process, which is the sum of the multiplications of normalized matrix $\mathrm{R}$ with the weight vector so that the greatest value is chosen as an alternative (Ai) as the solution.

The strength of the Simple Additive Weighting method compared to other decision-making models is in its ability to make more precise assessments because it is based on predetermined criteria values and weights, besides that the SAW can also select the best alternatives from some alternatives because there is a ranking process after determining the weights for each attribute.

\section{HASIL}

Based on the steps that have been discussed and the formula for making a matrix for normalization with the SAW method in the discussion of the method in Figure 1, the calculations obtained according to the steps are as follows: 
Table 1. Preference Weighting Criteria

\begin{tabular}{cccc}
\hline Rating Indicator & Criteria & Scale & Weight \\
\hline Communication & C1 & 3.00 & 0.12 \\
Accuracy & C2 & 4.00 & 0.16 \\
Thorough & C3 & 5.00 & 0.2 \\
Transaction Amount & C4 & 3.00 & 0.12 \\
Work duration & C5 & 5.00 & 0.2 \\
Liveliness & C6 & 5.00 & 0.2 \\
\hline
\end{tabular}

Table 2. Rating Interval

\begin{tabular}{cccccccc}
\hline Interval & C1 & C2 & C3 & C4 & C5 & C6 & Value Weight \\
\hline Very less & 1 & 1 & 1 & 2.00 & 5 & 0 & 0 \\
Less & 2 & 2 & 2 & 4.00 & 4 & 1 & 1 \\
Enough & 3 & 3 & 3 & 6.00 & 3 & 2 & 2 \\
Well & 4 & 4 & 4 & 8.00 & 2 & 3 & 3 \\
Very good & 5 & 5 & 5 & 10.00 & 1 & 4 & 4 \\
\hline
\end{tabular}

Table 3. The Value of PT Copindo Renanta Technicians

\begin{tabular}{ccccccc}
\hline Alternative & C1 & C2 & C3 & C4 & C5 & C6 \\
\hline Radi Sanjaya (A1) & 2.5 & 4.75 & 3.5 & 4 & 2 & 1 \\
Asep Saepullah (A2) & 3.5 & 3.5 & 4 & 4 & 3 & 2 \\
Riko Jayanto (A3) & 1.8 & 2 & 1.8 & 5 & 4.8 & 0 \\
Agung (A4) & 4 & 2 & 2 & 1 & 1 & 2 \\
Zulkarnain (A5) & 5 & 4 & 3 & 1 & 1 & 3 \\
Sopyan (A6) & 5 & 3 & 4 & 1 & 1 & 2 \\
Halili Bakti (A7) & 3 & 5 & 5 & 1 & 1 & 1 \\
Sarna Pramono (A8) & 4 & 3 & 2 & 1 & 1 & 2 \\
Mulyadi (A9) & 4 & 5 & 3.5 & 2 & 1 & 1 \\
Sony Wicaksono (A10) & 4.5 & 4.5 & 3 & & & 3 \\
Alfinsyah (A11) & 4 & & 5 & & & 2 \\
\hline
\end{tabular}

Table 4. The Weight Value of PT Copindo Renanta Technicians

\begin{tabular}{ccccccc}
\hline Alternative & $\mathbf{C 1}$ & $\mathbf{C 2}$ & $\mathbf{C 3}$ & $\mathbf{C 4}$ & $\mathbf{C 5}$ & $\mathbf{C 6}$ \\
& $+\boldsymbol{+}$ & $\mathbf{+}$ & $\boldsymbol{+}$ & $\boldsymbol{+}$ & $\boldsymbol{-}$ & $\mathbf{+}$ \\
\hline Radi Sanjaya (A1) & 1 & $\mathbf{0 . 1 6}$ & $\mathbf{0 . 2}$ & $\mathbf{0 . 1 2}$ & $\mathbf{0 . 2}$ & $\mathbf{0 . 2}$ \\
Asep Saepullah (A2) & 2 & 2 & 2 & 1 & 3 & 1 \\
Riko Jayanto (A3) & 0 & 1 & 3 & 1 & 2 & 2 \\
Agung (A4) & 3 & 1 & 0 & 1 & 1 & 0 \\
Zulkarnain (A5) & 4 & 3 & 1 & 0 & 4 & 2 \\
Sopyan (A6) & 4 & 2 & 3 & 0 & 4 & 3
\end{tabular}




\begin{tabular}{ccccccc} 
Halili Bakti (A7) & 2 & 4 & 4 & 0 & 4 & 1 \\
Sarna Pramono (A8) & 3 & 2 & 3 & 0 & 4 & 2 \\
Mulyadi (A9) & 3 & 4 & 1 & 0 & 4 & 2 \\
Sony Wicaksono (A10) & 3 & 3 & 2 & 0 & 4 & 1 \\
Alfinsyah (A11) & 3 & 2 & 4 & 0 & 4 & 3 \\
& $\mathrm{MAX}=4$ & $\mathrm{MAX}=4$ & $\mathrm{MAX}=4$ & $\mathrm{MAX}=1$ & $\mathrm{MIN}=4$ & $\mathrm{MAX}=3$ \\
\hline
\end{tabular}

In the case of the assessment of PT Copindo Renanta's technicians C1, C2, C3, C4 and C6 are profit attributes then:

$$
r_{i j}=\frac{x_{i j}}{\operatorname{Max}_{i} x_{i j}}
$$

And C5 is a cost attribute then:

$$
r_{i j}=\frac{\operatorname{Min}_{i} x_{i j}}{x_{i j}}
$$

Table 5. The Weight Value of PT Copindo Renanta Technicians

\begin{tabular}{ccccccc}
\hline Alternative & $\begin{array}{c}\text { C1 } \\
+\end{array}$ & $\begin{array}{c}\text { C2 } \\
+\end{array}$ & $\begin{array}{c}\text { C3 } \\
+\end{array}$ & $\begin{array}{c}\text { C4 } \\
+\end{array}$ & $\begin{array}{c}\text { C5 } \\
-\end{array}$ & $\begin{array}{c}\text { C6 } \\
+\end{array}$ \\
\hline Radi Sanjaya (A1) & $1 / 4$ & $3 / 4$ & $2 / 4$ & $1 / 1$ & $4 / 3$ & $1 / 3$ \\
Asep Saepullah (A2) & $2 / 4$ & $2 / 4$ & $3 / 4$ & $1 / 1$ & $4 / 2$ & $2 / 3$ \\
Riko Jayanto (A3) & $0 / 4$ & $1 / 4$ & $0 / 4$ & $1 / 1$ & $4 / 1$ & $0 / 3$ \\
Agung (A4) & $3 / 4$ & $1 / 4$ & $1 / 4$ & $0 / 1$ & $4 / 4$ & $2 / 3$ \\
Zulkarnain (A5) & $4 / 4$ & $3 / 4$ & $2 / 4$ & $0 / 1$ & $4 / 4$ & $3 / 3$ \\
Sopyan (A6) & $4 / 4$ & $2 / 4$ & $3 / 4$ & $0 / 1$ & $4 / 4$ & $2 / 3$ \\
Halili Bakti (A7) & $1 / 4$ & $3 / 4$ & $2 / 4$ & $1 / 1$ & $4 / 3$ & $1 / 3$ \\
Sarna Pramono (A8) & $2 / 4$ & $2 / 4$ & $3 / 4$ & $1 / 1$ & $4 / 2$ & $2 / 3$ \\
Mulyadi (A9) & $0 / 4$ & $1 / 4$ & $0 / 4$ & $1 / 1$ & $4 / 1$ & $0 / 3$ \\
Sony Wicaksono (A10) & $3 / 4$ & $1 / 4$ & $1 / 4$ & $0 / 1$ & $4 / 4$ & $2 / 3$ \\
Alfinsyah (A11) & $4 / 4$ & $3 / 4$ & $2 / 4$ & $0 / 1$ & $4 / 4$ & $3 / 3$ \\
\hline
\end{tabular}

Table 6. Matrix Normalization Results

\begin{tabular}{ccccccc}
\hline Alternative & C1 & $\mathbf{C 2}$ & $\mathbf{C 3}$ & $\mathbf{C 4}$ & $\mathbf{C 5}$ & $\mathbf{C 6}$ \\
& $\boldsymbol{+}$ & $\boldsymbol{+}$ & $\boldsymbol{+}$ & $\boldsymbol{+}$ & $\boldsymbol{-}$ & $\boldsymbol{+}$ \\
\hline Radi Sanjaya (A1) & $\mathbf{0 . 1 2}$ & $\mathbf{0 . 1 6}$ & $\mathbf{0 . 2}$ & $\mathbf{0 . 1 2}$ & $\mathbf{0 . 2}$ & $\mathbf{0 . 2}$ \\
Asep Saepullah (A2) & 0.25 & 0.75 & 0.5 & 1 & 0.33333 & 0.33333 \\
Riko Jayanto (A3) & 0.5 & 0.5 & 0.75 & 1 & 0.5 & 0.66667 \\
Agung (A4) & 0.75 & 0.25 & 0 & 1 & 1 & 0 \\
Zulkarnain (A5) & 1 & 0.25 & 0.25 & 0 & 0.25 & 0.66667 \\
Sopyan (A6) & 1 & 0.5 & 0.5 & 0 & 0.25 & 1 \\
& & & 0.75 & 0 & 0.25 & 0.66667
\end{tabular}




\begin{tabular}{ccccccc} 
Halili Bakti (A7) & 0.5 & 1 & 1 & 0 & 0.25 & 0.33333 \\
Sarna Pramono (A8) & 0.75 & 0.5 & 0.75 & 0 & 0.25 & 0.66667 \\
Mulyadi (A9) & 0.75 & 1 & 0.25 & 0 & 0.25 & 0.66667 \\
Sony Wicaksono (A10) & 0.75 & 0.75 & 0.5 & 0 & 0.25 & 0.33333 \\
Alfinsyah (A11) & 0.75 & 0.5 & 1 & 0 & 0.25 & 1 \\
\hline
\end{tabular}

After obtaining the normalized results table, it is carried out to multiply each column in the table by weight criteria that have been declared previously by ranking:

$$
\mathrm{V}_{\mathrm{i}}=\sum_{\mathrm{j}=1}^{\mathrm{n}} \mathrm{w}_{\mathrm{j}} \mathrm{r}_{\mathrm{ij}}
$$

$\mathbf{A 1}=\left(0.25^{*} 0.12\right)+\left(0.75^{*} 0.16\right)+\left(0.5^{*} 0.2\right)$ $+(1 * 0.12)+(0.33333 * 0.2)+(0.33333 * 0.2)$ $=\mathbf{0 . 5 0 3 3}$

$\mathbf{A 2}=\left(0.5^{*} 0.12\right)+\left(0.5^{*} 0.16\right)+(0.75 * 0.2)+$ $(1 * 0.12)+(0.5 * 0.2)+(0.66667 * 0.2)=$ 0.6433

$\mathbf{A 3}=(0 * 0.12)+(0.25 * 0.16)+(0 * 0.2)+$ $(1 * 0.12)+(1 * 0.2)+(0 * 0.2)=\mathbf{0 . 3 6 0 0}$

$\mathbf{A 4}=(0.75 * 0.12)+(0.25 * 0.16)+(0.25 * 0.2)$ $+(0 * 0.12)+(0.25 * 0.2)+(0.666666667 * 0.2)$ $=0.3633$

$\mathbf{A 5}=(1 * 0.12)+(0.75 * 0.16)+(0.5 * 0.2)+$ $(0 * 0.12)+(0.25 * 0.2)+(1 * 0.2)=\mathbf{0 . 5 9 0 0}$

A6 $=(1 * 0.12)+(0.5 * 0.16)+(0.75 * 0.2)+$ $(0 * 0.12)+(0.25 * 0.2)+(0.666666667 * 0.2)$ $=\mathbf{0 . 5 3 3 3}$

A7 $=(0.5 * 0.12)+(1 * 0.16)+(1 * 0.2)+$ $(0 * 0.12)+(0.25 * 0.2)+(0.333333333 * 0.2)=$

\subsection{7}

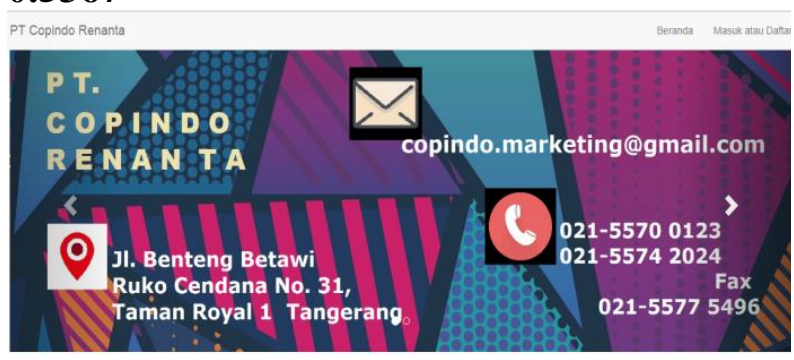

$\mathbf{A 8}=(0.75 * 0.12)+(0.5 * 0.16)+(0.75 * 0.2)$ $+(0 * 0.12)+(0.25 * 0.2)+(0.666666667 * 0.2)$ $=\mathbf{0 . 5 0 3 3}$

A9 $=\left(0.75^{*} 0.12\right)+(1 * 0.16)+\left(0.25^{*} 0.2\right)+$ $(0 * 0.12)+(0.25 * 0.2)+(0.666666667 * 0.2)=$ 0.4833

$\mathbf{A 1 0}=(0.75 * 0.12)+\left(0.75^{*} 0.16\right)+(0.5 * 0.2)$ $+(0 * 0.12)+(0.25 * 0.2)+(0.333333333 * 0.2)$ $=0.4267$

$\mathbf{A 1 1}=\left(0.75^{*} 0.12\right)+(0.5 * 0.16)+(1 * 0.2)+$ $(0 * 0.12)+(0.25 * 0.2)+(1 * 0.2)=\mathbf{0 . 6 2 0 0}$.

Table 7. Vector Preference and Ranking (Results)

\begin{tabular}{ccc}
\hline Rank & Name & Results \\
\hline 1 & Asep Saepullah & 0.6433 \\
2 & Alfinsyah & 0.62 \\
3 & Zulkarnain & 0.59 \\
4 & Halili Bakti & 0.5367 \\
5 & Sopyan & 0.5333 \\
6 & Sarna Pramono & 0.5033 \\
7 & Radi Sanjaya & 0.5033 \\
8 & Mulyadi & 0.4833 \\
9 & Sony Wicaksono & 0.4267 \\
10 & Agung & 0.3633 \\
11 & Riko Jayanto & 0.36 \\
\hline
\end{tabular}

Figure 4: Main Page Views

This is the main page display, on this page the client or admin can choose their own login. 


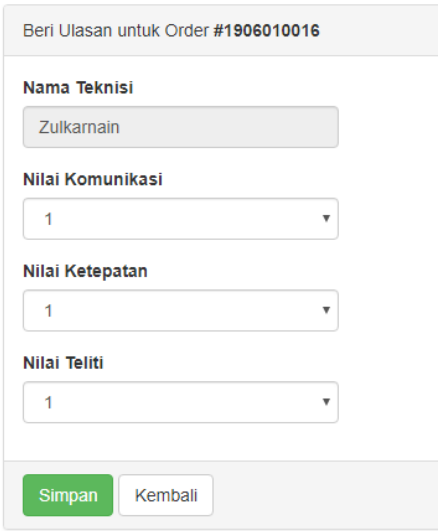

Figure 5: Review Page Views

On this page the client is asked to provide their review of the performance of the technician who will be used as material for calculation using the SAW method.

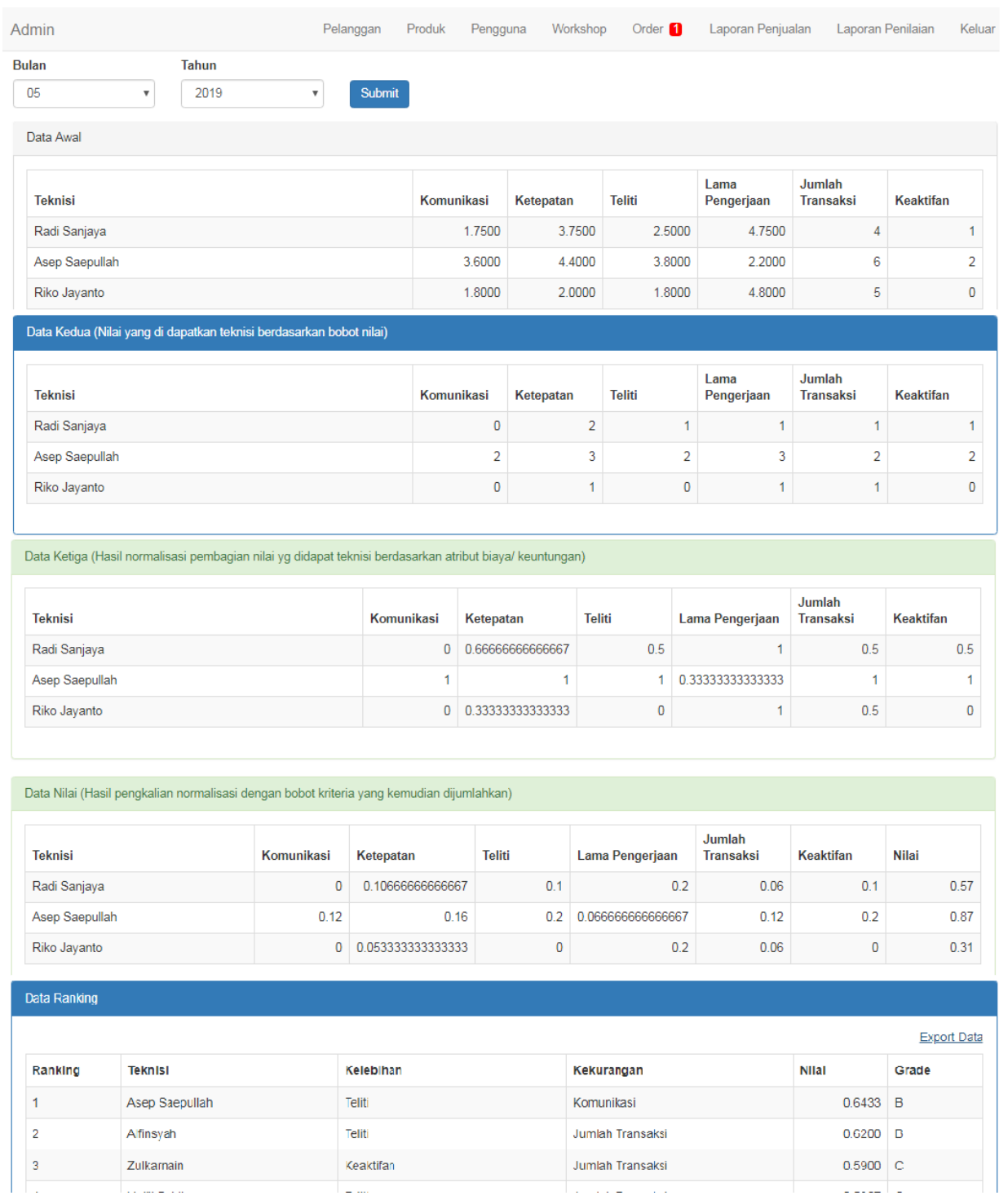

Figure 6: Assessment Report Page Views 
The page in Figure 6, the admin can see the calculation of the performance assement of the technician using the SAW method with predetermined criteria for making a performance rank report of the technician based on the desired period of months.

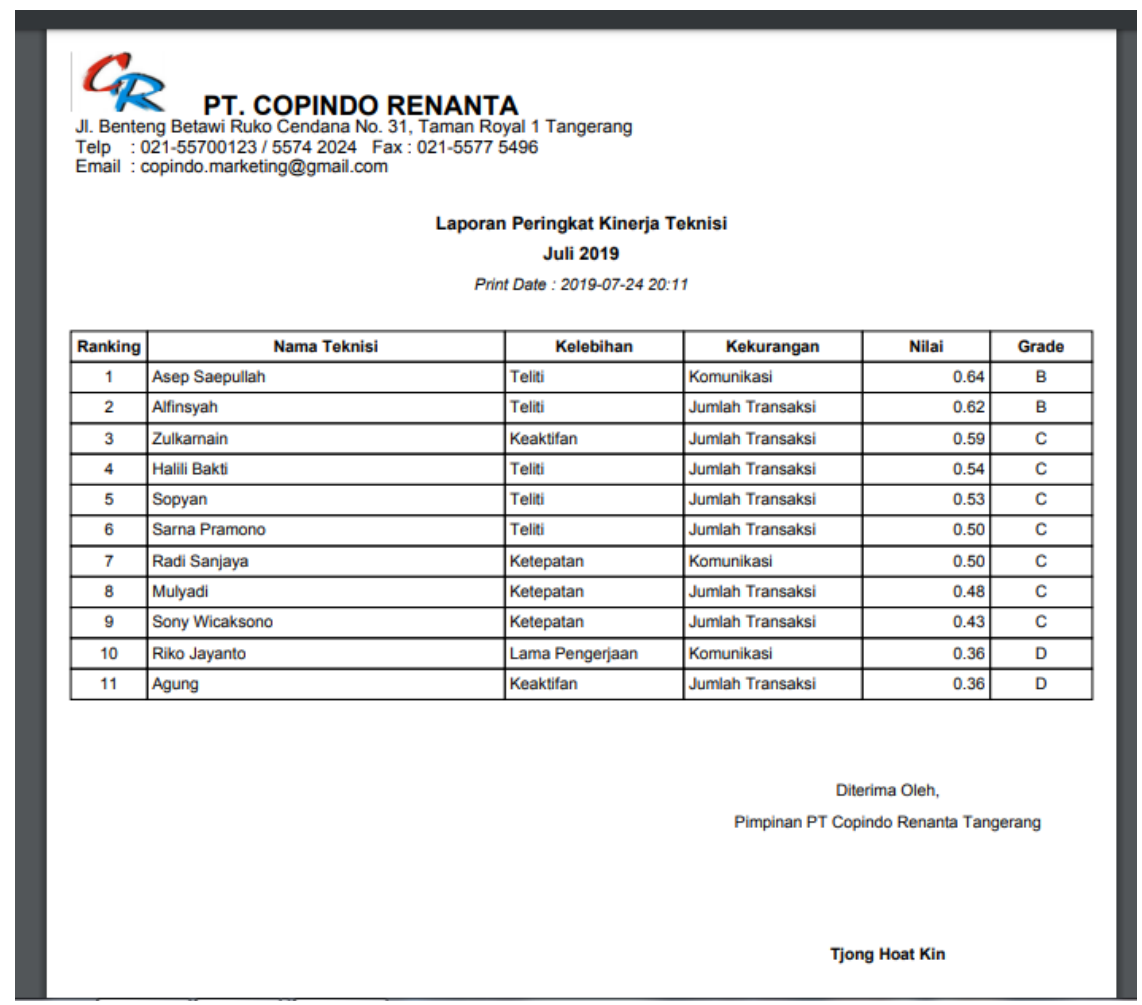

Figure 7: Export the Assessment's Report Views

On this page the admin can download or print a technician's performance ranking report.

\section{DISCUSSION}

After analyzing the current system at PT Copindo Renanta, the author can conclude that there are still some problems that exist in the running system. The weaknesses of the current system are as follows:

1. Still order a copy machine repair service by manually, starting from ordering service transactions only on weekdays by coming or calling the company, until a copy machine repair service report is recorded manually.

2. The technician's performance processing is still done manually with a paper service satisfaction form given to customers that can be manipulated become a thing that are less of concern so that the company cannot assess customer satisfaction with the true service of the technicians.

3. When the owner of the company wants to know the performance of the technician, the admin makes a technician's performance report based on the service satisfaction form filled in by the customer by adding a score that is feels inaccurate.

So with these weaknesses, the authors make the Requirements Elicitation that have been given to the user, here are some system requirements that are filled by PT Copindo Renanta:

a) Create a system for calculating technician ratings based on desired criteria.

b) Making a system with ranking of technicians.

c) Making a system that can make reservations on holidays even though it will be processed on weekdays.

d) Making a website-based system in order to help save telephone costs.

e) Have a list of costs and a list of spare parts needed from customer transactions. 
f) Client can fill the satisfaction of service technicians.

g) Making the system by being able to login and register an account first.

h) Gives the status of the transaction to what extent through the system.

i) Provide invoices for clients.

j) Make reports easily.
Based on the system requirements expected by PT Copindo Renanta, in figure 8 is a system activity diagram that is made according to company needs.

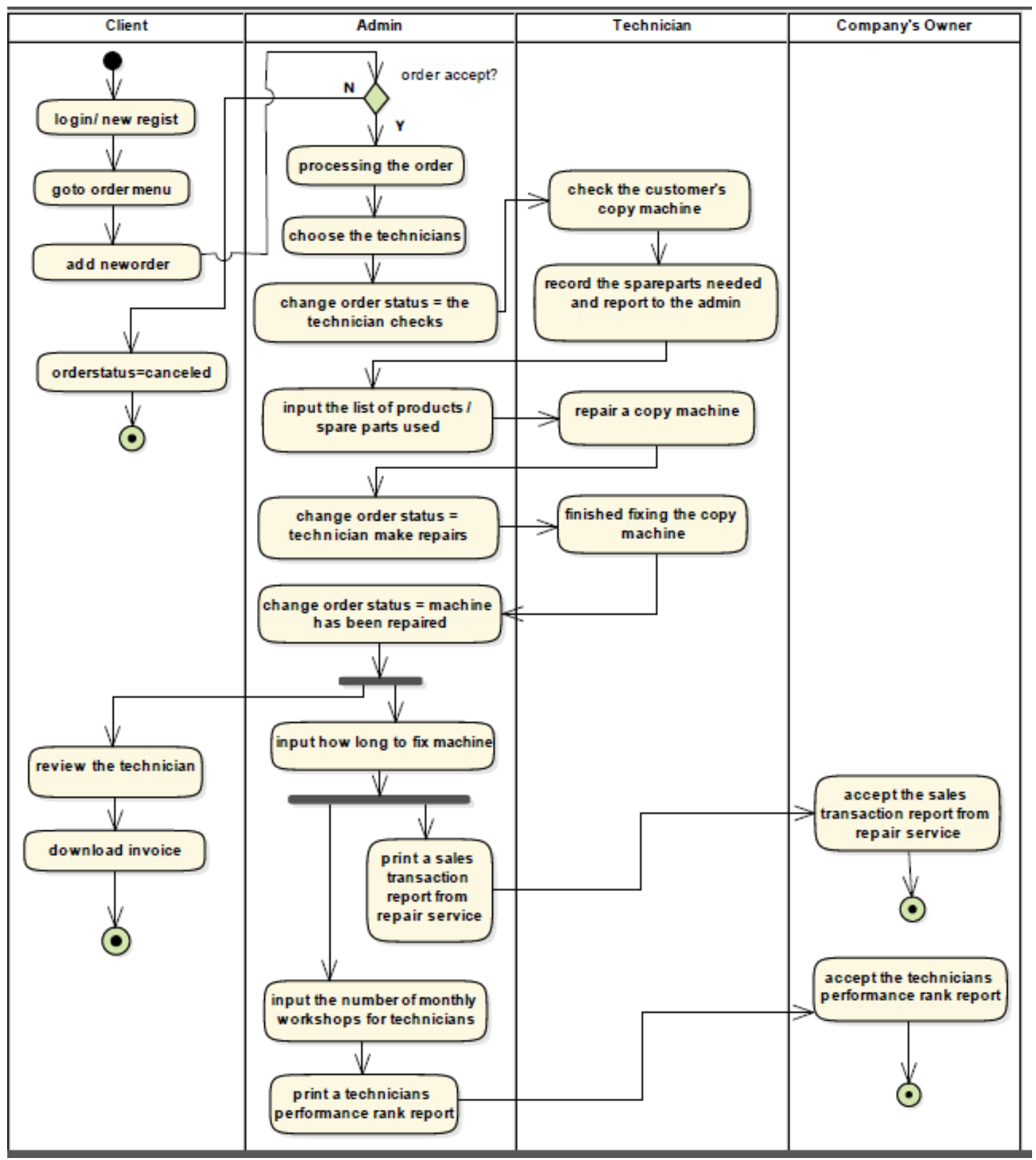

Figure 8: Proposed Systems Activity Diagram 


\section{CONCLUSION}

The conclusions obtained after looking at the program and the descriptions in the previous chapters are as follows:

1. For companies engaged in services, the quality of service becomes priority in establishing long-term relationships with their customers. The quality of service that become the primary key, is obtained from technicians who repair photocopying machines of PT Copindo Renanta customers.

2. This system is very helpful and supports companies in improving the quality of services from photocopier repair services because this system can be used easily and quickly, wherever and whenever needed.

3. This system provides the results of technician performance calculations from photocopier repair services accurately and trusted because the calculations are carried out by the SAW method based on several values from the criteria entered by the customer.

4. With this system, reducing the use of paper and a files will be stored correctly. 


\section{REFERENCES}

[1] Diana, \& Setiawati, Sistem Informasi Akuntansi, Yogyakarta : Andi Offset, 2011. Sucipto, Konsep dan Teknik Pengembangan Sistem Berbasis Teknologi Informasi, Serang : Dinas Pendidikan Provinsi Banten, 2011.

[2] O’Brien, J. A, Introduction of Information System, New York : McGraw-Hill Inc, 2010.

[3] Sucipto, Sistem Informasi Manajemen Berbasis Tren Teknologi, Serang : Dinas Pendidikan Provinsi Banten, 2012.

[4] Pratomo Setiaji, "Sistem Pendukung Keputusan Dengan Metode Simple Additive Weighting", Jurnal Universitas Muria Kudus, vol. 1, no.1, 2015 hh. 1-3.

[5] Mandala, Hendry \& Putra, "Sistem Pendukung Keputusan Pemilihan Karyawan Berprestasi di Pertamina Pengapon Semarang Dengan Metode Simple Additive Weighting" , Jurnal Universitas Dian Nuswantoro, vol. 1, no. 4, 2014, hh. 1-7.

\section{BIOGRAPHY}

Thessa Seftiani Dewi, born in Cilegon city on September 22 ${ }^{\text {nd }}, 1995$. Finished D3 (Amd. Kom.) at Buddhi Dharma University, Tangerang on 2016. Currently active as a Teller Bakti at PT Bank Central Asia, Tbk since 2017.

Dram Renaldi, Completed his undergraduate education (S.Kom.) at STMIK PGRI Tangerang on 2012 and his postgraduate education (M.Kom.) at Budi Luhur University on 2016. Now active as a permanent lecturer and head of the Software Engineering study program at Buddhi Dharma University. 